\title{
MEETING OF THE COUNCIL OF DELEGATES
}

The Council of Delegates, comprising representatives of the ICRC, the League and the National Societies, met in Geneva on 3 October, under the chairmanship of Mr. Alexandre Hay, ICRC President. The Council adopted the following resolutions:

\section{RESOLUTION 1}

\section{Re-appraisal of the role of the Red Cross}

The Council of Delegates,

mindful of Resolution II of the Twenty-third International Red Cross Conference on the "Re-appraisal of the Role of the Red Cross",

takes note of the report presented by the International Committee of the Red Cross and the League of Red Cross Societies,

approves the constitution of the three joint ICRC-League working groups on:

\section{- assistance}

- National Society development, and

- information,

recommends all National Societies to continue the re-appraisal process initiated by the Study, particularly by analysing their own strengths and weaknesses both in their organisations and in their activities, and by drawing practical conclusions,

considers that the ICRC and the League should continue their reflection as part and parcel of their normal activities, taking the Study as a helpful guide. 


\section{RESOLUTION 2}

Ratifications and accessions to the Protocols additional

The Council of Delegates,

recalling the resolution on "the Geneva Conventions and the additional Protocols", adopted by the XXIIIrd International Conference of the Red Cross, and which "expresses the wish that the additional Protocols be signed and ratified, or acceded to, as soon as possible, so that they become as universally accepted as the Geneva Conventions",

noting that the additional Protocols, which were signed by some sixty States, have thus far received some ten ratifications or accessions,

convinced that the international community by adopting on 8 June 1977 the two additional Protocols gave expression to its earnest desire to relieve the suffering caused by armed conflicts and to protect the civilian population against their evils whenever such situations still occur,

having heard the report of the International Committee of the Red Cross on its activities with a view to promoting the ratification of, or accession to, the Protocols,

aware that ratification of, or accession to, the Protocols requires careful consideration by the responsible authorities,

1. reaffirms the goal that the two additional Protocols become as universally accepted as the Geneva Conventions,

2. commends the International Committee of the Red Cross for its endeavours towards the realization of this goal, and invites it to continue its efforts in this respect,

3. urges the National Red Cross (Red Crescent, Red Lion and Sun) Societies in States which have not yet ratified or acceded to the Protocols, where necessary in co-operation with the International Committee and the League, to do their utmost to speed up the requisite procedures in their respective countries with a view to seeing the ratification of, or accession to, the Protocols achieved as soon as possible. 


\section{RESOLUTION 3}

Dissemination of international humanitarian law and Red Cross principles and ideals

The Council of Delegates,

having read with interest the ICRC and League report on the dissemination of international humanitarian law and ot the principles and ideals of the Red Cross, and having read also with interest the programme of action for dissemination,

adopts that report,

congratulates the ICRC, the League and the Henry Dunant Institute for establishing the said programme of action,

encourages National Societies to give their support to efforts to achieve the objectives of the programme of action,

notes with satisfaction the constitution and the activity of a Working Group of experts to assist and advise Red Cross institutions in the application of the programme of action,

asks the ICRC, the League and the working group to continue their efforts for the dissemination of international humanitarian law and the principles and ideals of the Red Cross and to report thereon to the next Council of Delegates in accordance with the spirit of Resolution VII of the Twenty-third International Conference of the Red Cross.

\section{RESOLUTION 4}

\section{Peace and disarmament}

The Council of Delegates,

calling to mind the mission of the Red Cross as defined in Resolution I of the 23rd International Conference of the Red Cross,

re-affirming that the Red Cross as a universal humanitarian movement cannot be indifferent to the key problems of the modern world and is called upon to contribute to their solution within the scope of its mission, 
being convinced that recognition and dissemination of humanitarian principles and ideals help to solve the problems of peace and disarmament,

1. expresses its solidarity with the efforts of nations and governments to consolidate and strengthen international peace and to curb the arms race,

2. welcomes all further endeavours which give satisfaction to all parties concerned and reduce the threat of war by disarmament,

3. calls upon the League, the ICRC and National Societies to take practical measures to implement the programme of action of the Red Cross as a factor of peace and the resolutions adopted by the international statutory bodies of the Red Cross on the promotion of the cause of peace,

4. calls upon the League, the ICRC and National Societies to cooperate more closely in their respective activities with institutions and organizations working for international peace,

5. calls upon the League, the ICRC and National Societies to acquaint public opinion with the efforts of the Red Cross to promote international peace.

\section{RESOLUTION 5}

\section{Development of the activities of the Henry Dunant Institute}

The Council of Delegates,

having considered the report of the Henry Dunant Institute on its activities since the XXIIIrd International Red Cross Conference (Bucharest, October 1977),

takes note thereof and expresses its appreciation of the work carried out by the Institute with modest resources,

pays an earnest tribute to Mr. Jean Pictet for the signal service he has rendered as director of the Henry Dunant Institute since 1975, thereby contributing to the Institute's development and influence, and expresses to him its profound gratitude for his work, 
underlines the role of the Henry Dunant Institute as an instrument for Red Cross study, research, training, teaching and dissemination available to all members of the International Red Cross,

asks the Henry Dunant Institute to continue and intensify its efforts in its fundamental tasks, namely:

- by developing its research into various aspects of past and present activities of the Red Cross in time of peace and of war, with a view to reaching practical conclusions for the development of the movement's activities,

- by encouraging the periodical organisation of courses, lectures on the Red Cross for the benefit of leaders and senior staff of National Societies as well as seminars on International Humanitarian Law, more particularly for the benefit of public servants, diplomats, University professors and students,

- by disseminating the results of its work as widely as possible, thereby contributing to make the Red Cross better known within and without the Red Cross,

recommends the Institute to intensify its co-operation with the National Red Cross, Red Crescent and Red Lion and Sun Societies, and also recommends the National Societies to give support to the activities of the Institute and to provide it, to the extent they can afford, with the material means that will enable it to expand its action.

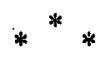

On several of its agenda items, the Council of Delegates did not adopt resolutions.

It took note of an interim report on the promotion of the Red Cross image dealing with the International Red Cross concept and the setting up of a joint ICRC-League audio-visual centre.

A document on torture reviewed the scope for Red Cross action in the struggle to eliminate that scourge: visits to detainees and reporting on detention conditions. The same document discussed existing legal instruments (Geneva Conventions, Universal Declaration of Human Rights) and draft conventions currently being considered with a view to banning torture.

The President of the ICRC, as chairman of the working group on the emblem, a group whose founding was decided upon during the Twenty- 
third International Red Cross Conference (Bucharest, 1977), reported orally. Consultation of the National Societies has been undertaken by means of a questionnaire. The commission will continue its work.

The struggle against racial discrimination was also brought to the Council's attention. It was reminded that everything undertaken by the Red Cross contributed to the struggle against all forms of discrimination.

The Council's attention was drawn to the Maurice de Madre French Fund (see International Review of the Red Cross, Jan.-Feb., 1979). The National Societies were informed of the conditions under which they could apply to the Fund.

The Council did reach some decisions worth noting even though they were not the subject of a formally adopted text:

\section{Commission on the Red Cross and Peace}

The Commission's report was adopted. The Commission, whose composition remained unchanged, was extended until the Twentyfourth International Red Cross Conference (Manila, 1981). Its terms of reference were also unchanged, but the Commission is authorized to decide precisely the tasks covered by its terms of reference.

2. Duration of Council of Delegate meetings

The International Red Cross Standing Commission was requested to examine the following proposal: the duration of a meeting of the Council of Delegates between Conferences shall be at least two days.

3. Assistance to the families of Red Cross personnel who die in the course of their duties

The Council urged the ICRC and the League to make proposals to National Societies with a view to assistance from the movement as a whole to the families of Nicaraguan Red Cross personnel who lost their lives in Red Cross service during the recent fighting in that country. The activities of the fund of which the creation is envisaged would not, incidentally, be confined to Nicaragua. 